\title{
PERUBAHAN DAN ANCAMAN \\ BENTENG KERATON BUTON DI KOTA BAU-BAU SULAWESI TENGGARA
}

\author{
Dewi Susanti \\ Balai Pelestarian Cagar Budaya Sulawesi Selatan \\ Email : dewisusantiarkeo_02@yahoo.com
}

\begin{abstract}
Abstrak: Benteng Keraton Buton berada di jalan Sultan Labuke, Kelurahan Melai, Kecamatan Murhum, Kota Bau-Bau. Metode yang digunakan dalam tulisan ini adalah pengumpulan data berupa pengumpulan data pustaka, dan pengamatan langsung di lapangan. Tahap selanjutnya adalah pengolahan data, tahapan ini dilakukan untuk mempermudah dalam proses analisis data yang telah diperoleh dan dapat menjadi dasar untuk menentukan upaya-upaya penanganan yang akan dilakukan. Tulisan ini mencoba menglasifikasikan ancaman yang terjadi pada Kawasan Benteng Keraton Buton dan upaya yang bisa ditawarkan. Kondisi Benteng Keraton Buton telah banyak mengalami perubahan baik dari lahan maupun bangunan. Perubahan yang terjadi mengakibatkan terjadinya kerusakan pada beberapa kondisi asli dari Benteng Keraton Buton. Perubahan yang terjadi pada lingkungan dan bangunan yang ada di dalam kawasan Benteng Keraton Buton berupa perluasan pemukiman, perluasan lahan pertanian, pemakaman, modernisasi, dan kebijakan pemerintah. Upaya untuk mencegah terjadi perubahan yang lebih signifikan pada Benteng Keraton Buton yaitu melalui upaya pelindungan dalam bentuk zonasi dengan tujuan dengan adanya zonasi maka pemanfaatan ruang dan bangunan dapat diatur sesuai dengan peruntukannya.
\end{abstract}

Kata Kunci: Benteng Keraton Buton, Perubahan, Ancaman, dan Masyarakat

Abstract: The Fortress of Buton Court is located on Jalan Sultan Labuke, Melai Village, Murhum Sub-district, Bau-bau. The methodology used in this paper is data collecting through library research and fieldwork. The next step is data processing to help the analysis and bases for future intervention efforts. This paper tries to classify the treat levels for the fortress area and suggest the solutions. The condition of the Fortress of Buton Court has undergone both landscape and structural change. The change has caused damage on the original condition of the fortress. The change happened can be classified into settlement expansion, agricultural extension, cemetery, modernization and governmental policies. The protection can be achieved by developing a zoning system to regulate the spatial and structural use of the fortress.

Keywords: The Fortress of Buton Court, Change, Treat Level, and Community

\section{PENDAHULUAN}

\section{I.1. Latar Belakang}

Benteng Keraton Buton telah menjadi landmark Kota Bau-Bau sekaligus ikon kebanggaan bagi masyarakat Buton dan Sulawesi Tenggara. Perubahan fungsi Kompleks Keraton Buton menjadi hal yang tidak terelakkan, baik dari segi penambahan pemukiman maupuan perubahan fungsi lahan dalam benteng. Jumlah penduduk yang terus bertambah dan pemanfaatan lahan yang semakin tidak terkendali, mengakibatkan perubahan fungsi ruang terbuka menjadi pemukiman penduduk. Selain itu perubahan cukup signifikan yang terjadi dalam kawasan benteng adalah bentuk bangunan rumah. Bentuk awal bangunan rumah yang ada di dalam kawasan benteng yaitu bangunan rumah panggung yang mencirikan khas Buton. Seiring dengan perkembangan jaman dan teknologi bangunan rumah penduduk saat ini berubah menjadi bangunan rumah batu. Melihat perubahan yang terjadi di dalam kawasan benteng yang semakin menghilangkan identitas pemukiman Buton, muncul inisiatif Pemerintah Kota Bau-Bau menerbitkan Surat Keputusan Walikota Bau-Bau No. 105 tahun 2003 tentang Penetapan Benteng Keraton sebagai Kawasan Khusus Kota Bau-Bau yang mengatur upaya pelestarian kawasan Benteng Keraton Buton.

Pada kenyataannya, peraturan tersebut tidak berjalan efektif, hal tersebut dapat dibuktikan dengan masih banyaknya pelanggaran yang terjadi di kawasan tersebut. Salah satu pelanggaran yang terjadi adalah semakin banyaknya bangunan rumah yang tidak bercirikan arsitektur lokal Buton. Hal ini, tentu menjadi potensi ancaman terhadap kelestarian Kompleks Benteng Keraton Buton. Berangkat dari hal tersebut di atas, diperlukan tindakan dan langkah-langkah yang menjamin kelestaraian Kompleks Benteng Keraton Buton untuk kepentingan masa yang akan datang. 
Upaya untuk melakukan pelestarian kawasan Benteng Keraton Buton, akan dilaksanakan sesuai dengan amanah yang tercantum dalam Undang-Undang No. 11 tahun 2010 tentang Cagar Budaya. Pelestarian merupakan upaya yang dilakukan untuk mempertahankan keberadaan Cagar Budaya dan nilai yang terkadung didalamnya, dengan cara melindungi, mengembangkan, dan memanfaatkannya. Berdasarkan amanah UndangUndang dan berdasarkan hasil pengamatan di lapangan mengenai kondisi kawasan Benteng Kraton Buton yang cukup tinggi potensi ancamannya. Saat ini, benteng Keraton Buton mengalami kerusakan pada bagian dinding benteng karena daya rekat antar batu telah berkurang. Selain itu, dalam kawasan Benteng ini banyak terjadi perubahan baik pada bangunan maupun pada lingkunganya. Perubahan yang terjadi tersebut, memberikan dampak yang negatif terhadap pelestarian kawasan benteng Keraton Buton, maka perlu segera dipikirkan untuk upaya penanganannya. Melalui tulisan ini penulis mencoba menglasifikasikan ancaman yang terjadi pada Kawasan Benteng Keraton Buton dan upaya yang bisa ditawarkan.

\section{I.2. Metode}

Metode yang digunakan dalam penulisan ini pertama adalah pengumpulan data yang diawali dengan penelusuran data pustaka. Tujuan pengumpulan data pustaka agar membantu untuk memberikan gambaran umum wilayah Benteng Kraton Buton, termasuk data administrasi, geotopografi, ekonomi, sosial, budaya, fasilitas yang tersedia dan lain-lain. Secara khusus, dapat pula diperoleh informasi arkeologis tentang tinggalantinggalan yang ada di dalam kawasan Benteng Kraton Buton. Langkah selanjutnya adalah pengumpulan data secara langsung di lapangan, yaitu di kawasan Benteng Keraton Buton dan sekitarnya. Dimulai dengan observasi secara langsung situs untuk memperoleh gambaran secara visual tentang situasi terakhir (exsisting condition). Informasi ini dapat berupa kondisi situs, keterawatan, sebaran temuan, potensi ancaman, ketersediaan lahan, serta potensi pengembangan dan pemanfaatan. Selain itu dapat pula memperdalam pemahaman tentang kondisi eksternal berupa apresiasi masyarakat terhadap obyek, kondisi sosial-ekonomi, sosial-budaya masyarkat sekitar, iklim, topografi, aturan-aturan yang terkait seperti perda,
RTRW, RIPDA, dan aturan adat yang tertulis maupun yang tidak tertulis.

Tahap pengolahan data, tahapan ini dilakukan setelah pengumpulan data pustaka dan data lapangan. Pengolahan data merupakan langkah untuk memudahkan proses analisis data, yang selanjutnya melahirkan sintesa sebagai hasil kolaborasi antara tuntutan ideal, pada tataran konseptual dengan kenyataan yang terjadi pada objek di lapangan. Keduanya kemudian dijadikan dasar untuk menentukan upaya-upaya penanganan yang akan dilakukan kedepannya.

\section{Deskripsi}

Benteng Keraton Buton berada di atas bukit dan secara administratif terletak di jalan Sultan Labuke, Kelurahan Melai, Kecamatan Murhum, Kota Bau-Bau. Keraton Buton yang terletak 5, $21^{\circ}-5,30$ LS dan 122, $30^{\circ}$ - 122, $45^{\circ}$ BT merupakan area bekas Ibukota kesultanan Buton. Benteng Keraton Buton telah diinventarisasi oleh kantor Balai Pelestarian Peninggalan Purbakala Makassar dengan nomor 459 dan telah ditetapkan sebagai cagar budaya dengan nomor: KM.8/PW.007/MKP-03, tanggal 4 Maret 2003, oleh Menteri Kebudayaan dan Pariwisata. Benteng tersebut terbuat dari batu karang yang disusun dengan menggunakan spesi yang terbuat dari batu kapur yang dihaluskan sebagai bahan perekat. Ukuran panjangnya 2.740 meter dengan ketebalan antara 1-2 meter dengan ketinggian antara 2-8 meter. Tata letak benteng mengikuti bentang lahan sehingga bentuknya menyerupai huruf "Dal" dalam aksara Arab. Jika dilihat dari luar, tampak adanya perbedaan ketinggian pada dinding benteng, hal ini disebabkan bentang lahan yang tidak rata sehingga dinding benteng yang berada di dekat lembah tampak lebih tinggi dibandingkan dengan daerah yang tanahnya rata.

Benteng Keraton Buton mempunyai 12 pintu gerbang (lawa) dan 16 bastion (baluara). Penamaan untuk tiap pintu gerbang disesuaikan dengan nama atau gelar orang yang mengawasinya. Keduabelas nama lawa tersebut adalah Lawana Rakia, Lawana Lanto, Lawana Labunta, Lawana Kampebuni, Lawana Waborobo, Lawana Dete, Lawana Kalau, Lawana Wajo/Bariya, Lawana Burukene/Tanailandu, Lawana Melai/Baau, Lawana Lantongau/Sambali, dan Lawana Gundu-Gundu. 


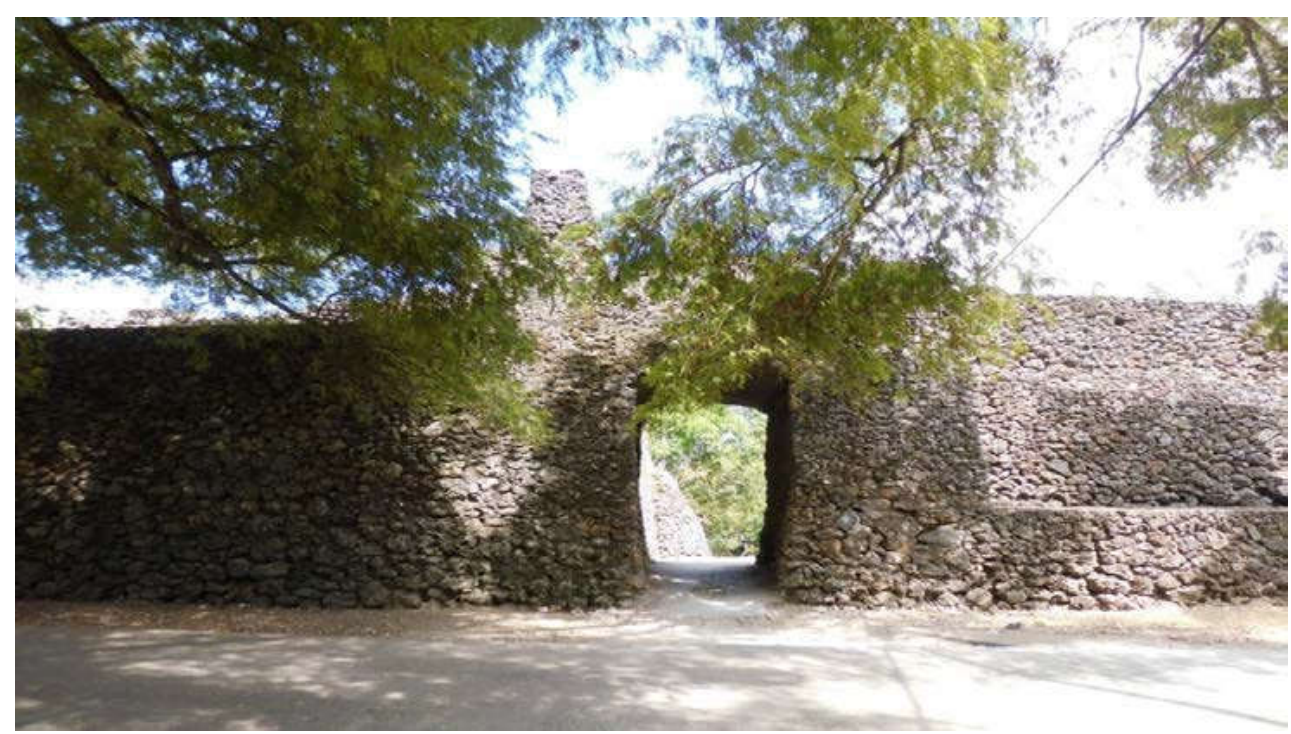

Gambar 1. Pintu gerbang (Lawana) Lantogau, salah satu lawa di benteng sisi barat (dok. BPCB Sul-Sel, 2012)

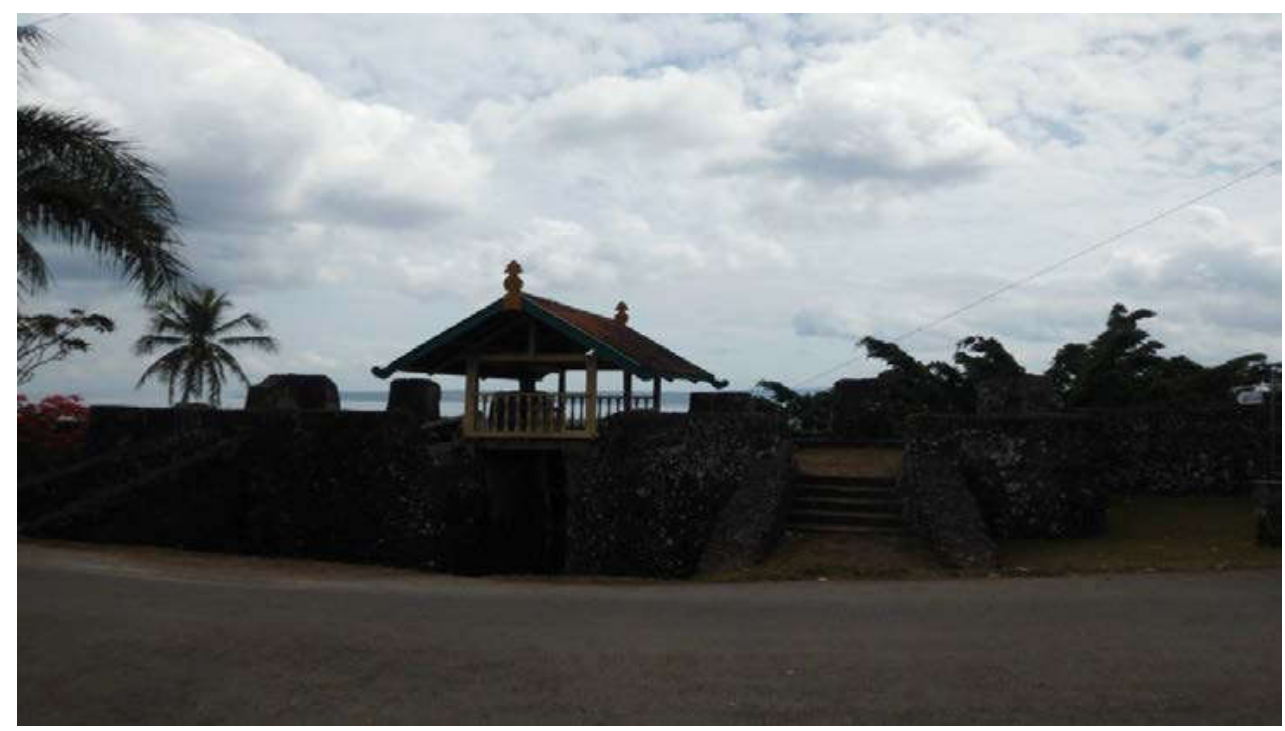

Gambar 2. Pintu gerbang (Lawana) Lanto, salah satu lawa di benteng sisi utara (dok. BPCB Sul-Sel, 2012)

Penyebutan "na" untuk lawa, digunakan pula pada bastion (baluara) yang disesuaikan dengan nama kampung tempat bastion tersebut berada (lihat gambar 3), yaitu: Baluarana Gama, Baluarana Litao/Waolima, Baluarana Barangkatopa, Baluarana Wandailolo, Baluarana Baluwu, Baluarana Dete, Baluarana Kalau, Baluarana Wajo/Bariya, Baluarana Tanailandu, Baluarana Melai/Baau, Baluarana Lantongau, Baluarana Gundu-Gundu, Baluarana Siompu, dan Baluarana Rakia. Selain baluara itu, terdapat dua baluara lain, yaitu Baluarana Godona Batu dan Baluarana Godona Oba yang difungsikan sebagai tempat penyimpanan peluru atau mesiu.
Dahulu kampung-kampung ini berada di kompleks Keraton Buton di sekitar bastion-bastion tersebut. Awalnya pemukiman ini hanya terdiri atas empat kampung yang dikenal dengan nama pata lipuna, yaitu Gundu-Gundu, Peropa, Baluwu, dan Barangkatopa, yang masing-masing dipimpin oleh seorang menteri (Bonto) (Zahari, 1977:29). Pada masa pemerintahan Tuarade (Raja Buton IV), perkampungan penduduk bertambah menjadi sembilan kampung yang disebut sio lipuna dengan penambahan kampung Sambali/Lantongau, Melai/Baau, Rakia, Gama, dan Wandailolo/Labunta (Zaenu, 1984:7-13). Pada masa, sekitar abad ke-17, berkembang lima kampung lagi yaitu Kampung Silea, Dete, Kalau, Kabumbu dan Kulandodo. 

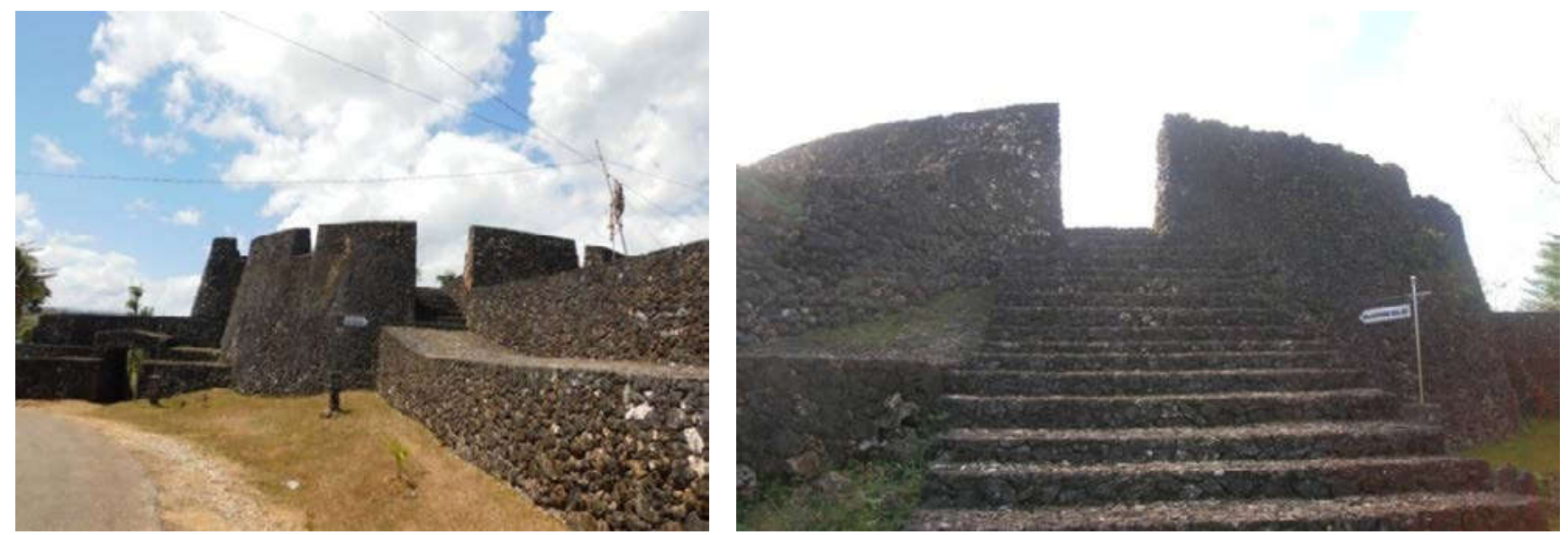

Gambar 3. Bastion (Baluarana) Gundu-gundu (kiri), salah satu bentuk bastion persegi pada sisi barat Baluarana Kalau (kanan). (Dok. Yadi Mulyadi, 2008)

Setiap pintu gerbang pada benteng Keraton Buton memiliki bentuk yang berbeda, dengan konstruksi batu yang dipadukan dengan kayu. Untuk pos jaga yang fungsinya sebagai pengintai, konstruksi bangunan yang digunakan terdiri dari campuran batu dan kayu. Bentuk bastion dapat dikelompokkan dalam dua bentuk yaitu bundar dan persegi panjang yang disesuaikan dengan fungsi dan kondisi lahan. Enam belas bastion di Benteng Keraton Buton, 11 di antaranya berbentuk persegi panjang, dan 5 lainnya berbentuk bundar. Berdasarkan hasil pengamatan, 11 bastion persegi panjang terletak di daerah yang menghadap lembah. Adapun bastion berbentuk bundar sebagian besar berada di lahan yang datar. Dari kelima bastion bundar, dua bastion difungsikan sebagai gudang penyimpanan peluru dan mesiu yaitu Bastion Godona Batu yang terletak di Kampung Lantongau dan Bastion Godona Oba yang terletak di Kampung Kalau. Bastion-bastion tersebut dilengkapi meriam berukuran besar. Sebagian meriam memiliki angka tahun 1658-1776 dengan cap bertuliskan VOC.

Berdasarkan keletakannya, bastion dapat dibagi menjadi dua yaitu bastion sudut (boka-boka) dan bastion samping (baluara). Di benteng ini, terdapat empat bastion sudut yang terletak pada ke empat sudut benteng yaitu boka-boka Gundu-Gundu, Jaraijo (kuda hijau), Godona Oba (gudang mesiu), Godona Batu (gudang peluru). Khusus boka-boka Gundu-Gundu dibuat bertingkat sehingga lebih tinggi dibanding ketiga boka-boka lainnya (Zahari, 1977:157). Adapun bastion samping (baluara) terletak pada sepanjang dinding benteng, yaitu Baluara Siompu, Rakia, Gama, Wandailolo, Barangkatopa,
Baluwu, Burukene, Dete, Kalau, Wajo Melai/Baau dan Lantongau/Sambali (Zahari, 1977).

Benteng Keraton Buton dibangun sekitar abad ke16 hingga abad ke-17 oleh masyarakat Buton pada masa pemerintahan Sultan Buton IV, Sultan La Elangi yang bergelar Dayanu Ikhsanuddin (1597-1631 M). Benteng ini kemudian diselesaikan pada masa pemerintahan Sultan Buton VI, Sultan La Buke yang bergelar Gafur Wadudu (1632-1645 M). Di masa lalu, di dalam benteng inilah pusat kegiatan pemerintahan dan pusat seluruh aktivitas kesultanan dijalankan (Iswadi, dkk, 2012) .

\section{PEMBAHASAN}

\subsection{Permasalahan/ Ancaman}

Berdasarkan dari data yang diperoleh pada saat pengumpulan data yang dilakukan pada tahun 2012 di Benteng Keraton Buton, diketahui bahwa aspek yang utama dalam permasalahan yang terjadi adalah aspek fisik dan aspek sosial budaya. Perubahan-perubahan yang terjadi pada kawasan Benteng Kraton Buton berupa pemanfaatan/penggunaan bangunan Cagar Budaya, penambahan bangunan baru di sekitar Cagar Budaya, dan perubahan struktur ruang kota.

a. Perubahan Struktur Ruang Benteng Keraton Buton 1. Pertumbuhan Penduduk

Penduduk Kota Bau-Bau menurut hasil sensus penduduk tahun 1990 berjumlah 77.224 orang dan sepuluh tahun kemudian tepatnya saat sensus penduduk tahun 2000 bertambah lagi hingga mencapai 106.092 orang. Mulai tahun 2001 Kota Bau-Bau beralih status dari 
kota adminisitratif menjadi Kotamadya. Seiring dengan peralihan status tersebut maka dibarengi juga dengan laju pertumbuhan penduduk yang mengakibatkan kepadatan terus meningkat dari tahun ke tahun. Jumlah penduduk Kota Bau-Bau pada tahun 2001 sebanyak 107.975 jiwa dengan jumlah kepala keluarga sebanyak 21.599 (Kota Bau-Bau dalam Angka, 2004). Pada tahun 2003, jumlah rumah tangga di Kotamadya Bau-Bau sebanyak 22.333 KK. Rata-rata rumah tangga terdiri atas lima jiwa. Persebaran penduduk di empat kecamatan terlihat bahwa 38, 90 $\%$ berada di Kecamatan Wolio, 10,08 \% berada di Kecamatan Bungi, 5,27 \% berada di Kecamatan Sorawolio, dan sisanya 45,75 \% penduduk berada di Kecamatan Betoambari.

Jumlah penduduk Kotamadya BauBau menurut hasil Sensus Penduduk (SP) tahun 1990 berjumlah 77.224 jiwa dan tahun 2000 mencapai 106.092 jiwa, terdiri dari 58.003 jiwa laki-laki dan 58.899 jiwa perempuan. Angka pertumbuhan ini dipicu oleh adanya pengungsi (eksodus) dari Ambon (Maluku) dan dari Timor Timur yang kembali ke Bau-Bau atau Buton karena menghindari kerusuhan. Kedatangan pengungsi memberi pengaruh besar terhadap perubahan yang terjadi di Buton pada umumnya dan Kotamadya Bau-Bau khususnya.

Pada tahun 2010 sensus penduduk kembali dilakukan oleh yang BPS,dari hasil sensus tersebut maka diperoleh data bahwa penduduk Kota Bau-bau mencapai jumlah 136.991 orang. Artinya dari 7 kecamatan yang ada di kota Bau-bau, semuanya mengalami tingkat pertumbuhan penduduk di atas 2 persen, sedangkan luas area Kota Bau-bau adalah $221 \mathrm{~km}^{2}$ maka kepadatan penduduk juga terus meningkat dari tahun ke tahun. Kepadatan penduduk Kota Bau-bau tahun 1990 sebesar 349 orang per $\mathrm{km}^{2}$ kemudian tahun 2000 sebesar 480 per $\mathrm{km}^{2}$. Kepadatan tertinggi terdapat di Kecamatan Murhum dengan luas wilayah terkecil yaitu sebesar
7.000 orang per $\mathrm{km}^{2}$, sedangkan Kecamatan Sorawolio dengan luas wilayah terbesar justru memiliki kepadatan penduduk terkecil yaitu sebesar 85 orang per $\mathrm{km}^{2}$.

Gambar 4. Perkembangan Penduduk Kota Bau-Bau Dari Tahun ke Tahun 2012

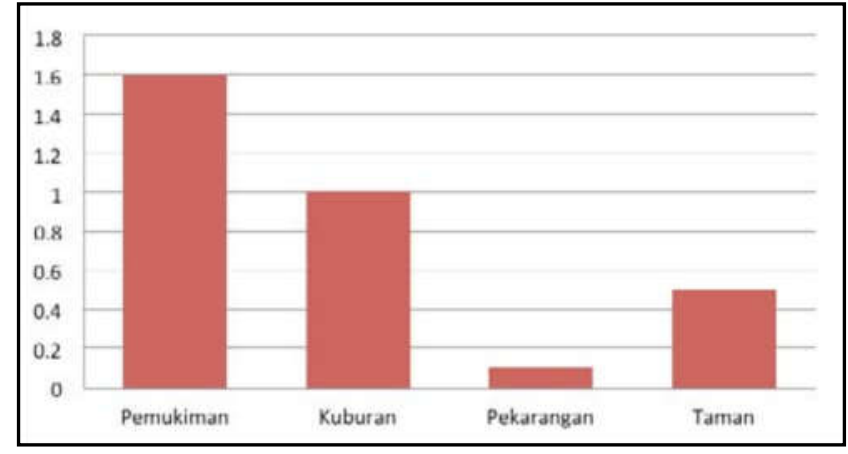

Sumber: BPS Kota Bau-Bau Tahun 2012

Berdasarkan hasil perolehan data pada kantor Badan pusat statistik kota Bau-Bau diketahui bahwa persebaran penduduk di Kota Bau-Bau sebagian besar tersebar di 4 kecamatan yang merupakan pusat perkotaan yaitu Kecamatan Murhum, Betoambari, sedangkan 3 kecamatan lainnya yang berada dipinggiran perkotaan persebaran penduduknya dibawah 6 persen. Pada Kecamatan Murhum dengan luas $6,45 \mathrm{~km}^{2}$ atau sekitar hanya 2,92 persen dari luas Kota Baubau yang mencapai luas $221.00 \mathrm{~km}^{2}$. Dengan jumlah penduduk 45.150 pada tahun 2010, dengan kepadatan penduduk sebesar 7,000 artinya setiap $\mathrm{km}^{2}$ terdapat 7.000 orang.

Jumlah penduduk tahun 2009 merupakan hasil proyeksi, sama halnya dengan jumlah penduduk pada tahun 2008. Pada tahun 2008 jumlah penduduk Kecamatan Murhum yakni 43.914 Jiwa, sedangkan pada tahun 2009 meningkat menjadi 44.986 Jiwa, dengan laju pertumbuhan penduduk sebesar 2,44 persen. Jumlah penduduk yang cukup besar dan terus bertambah setiap tahunnya tidak diimbangi dengan pemerataan penyebaran penduduk dan semakin tingginya tingkat kepadatan penduduk.

Perubahan ini dapat dilihat dari peningkatan jumlah penduduk yang cukup mencolok di Kotamadya Bau-Bau yang mencapai $50 \%$ dari jumlah sebelumnya. Selain 
itu, efek yang ditimbulkan oleh para pengungsi dari daerah Nusa Tenggara Timur terhadap lingkungan yaitu berupa pembangunan perumahan, pembukaan lahan-lahan baru di tanah kosong yang digunakan sebagai tempat tinggal dan bercocok tanam. Pengungsi umumnya ditempatkan di daerah yang luas dengan penduduk yang relatif sedikit yaitu di Kecamatan Sorawolio dan Kecamatan Bungi dalam satu perkampungan baru secara berkelompok. Dua kecamatan ini sebagian besar terdiri atas hutan dan perkebunan.

Tabel 1 . Luas Daerah, Jumlah Penduduk dan Kepadatan Penduduk menurut Kelurahan 2009

\begin{tabular}{|c|c|c|c|}
\hline Kelurahan & Luas Daerah $\left(\mathbf{k m}^{2}\right)$ & $\begin{array}{c}\text { Jumlah Penduduk } \\
\text { (Jiwa) }\end{array}$ & Kepadatan (Jiwa/Km) \\
\hline (1) & (2) & (3) & (4) \\
\hline Baadia & 2,00 & 2.215 & 1.108 \\
\hline Melai & 0,37 & 1.904 & 5.146 \\
\hline Wajo & 1,00 & 4.458 & 4.458 \\
\hline Lamangga & 0,78 & 5.369 & 6.883 \\
\hline Tanganapada & 0,75 & 4.041 & 5.388 \\
\hline Bone - Bone & 0,28 & 6.288 & 22.457 \\
\hline Tarafu & 0,42 & 5.005 & 11.917 \\
\hline Wameo & 0,18 & 4.698 & 26.100 \\
\hline Kaobula & 0,15 & 2.152 & 14.347 \\
\hline Lanto & 0,33 & 5.222 & 15.824 \\
\hline Nganganaumala & 0,19 & 3.634 & 19.126 \\
\hline Murhum & 6,45 & 44.986 & 6.975 \\
\hline
\end{tabular}

Sumber : Website Kota Bau-Bau

Tabel 2. Pembagian lahan dan persentase Luas Lahan Kelurahan Melai

\begin{tabular}{|c|l|c|c|}
\hline \multirow{2}{*}{ No } & \multicolumn{1}{|c|}{ Fungsi Lahan } & Luas (Ha) & Persentase \% \\
\hline 1 & Pemukiman & 1,6 & 45 \\
\hline 2 & Kuburan & 1 & 28 \\
\hline 3 & Pekarangan & 0,1 & 3 \\
\hline 4 & Taman & 0,5 & 14 \\
\hline 5 & Perkantoran & 0,05 & 1 \\
\hline 6 & Prasarana & 0,3 & 9 \\
\hline Jumlah & & 3,55 & 100 \\
\hline
\end{tabular}

Dari tabel mengenai pembagian lahan dan persentase luas lahan di Kelurahan Melai, diperoleh data bahwa lahan untuk pemukiman mendapatkan porsi terbesar dalam tata guna lahan di Kelurahan Melai yaitu sebesar 1,6 Ha atau 45 persen dan untuk lahan perkantoran hanya menyisikan $0,05 \mathrm{Ha}$ atau sebesar 1 persen dari keseluruhan lahan yang ada di Kelurahan Melai atau di dalam Benteng Keraton Buton.

Dari luas lahan Kelurahan Melai 0,37 $\mathrm{Km}^{2}$ atau 3,55 Ha, lahan yang digunakan untuk pemukiman adalah 1,6 Ha tersebut dihuni oleh 1.904 jiwa dengan kepadatan 5.146 atau setiap
$1 \mathrm{Km}^{2}$ dihuni oleh 5.146 jiwa. Dari luas lahan yang ada telah terbit 65 sertifikat dengan status hak guna pakai (sumber: Kantor Kelurahan Melai). Adapun jumlah rumah yang ada di dalam benteng berjumlah 332 rumah baik yang permanen maupun yang tidak permanen.

Untuk area di luar benteng di sebelah selatan merupakan bagian dari Kelurahan Baadia dengan luas 2,00 $\mathrm{Km}^{2}$, jumlah penduduk 2.215 jiwa dengan persentase kepadatan 1.108/ $\mathrm{Km}^{2}$ artinya setiap $1 \mathrm{Km}^{2}$ terdapat 1.108 jiwa yang bermukim di dalamnya, sedangkan pada sisi utara dan barat yang merupakan bagian dari 
Kelurahan Tanganapada dengan luas $0,75 \mathrm{Km}^{2}$ dengan jumlah penduduk 4.041 jiwa, kepadatan $5.388 / \mathrm{Km}^{2}$ artinya dalam $1 \mathrm{Km}^{2}$ terdapat 5.388 jiwa. Dengan melihat data tersebut di atas maka Kelurahan Tanganapada merupakan kelurahan dengan kepadatan tertinggi disusul oleh Kelurahan Melai, sedangkan Kelurahan Baadia merupakan kelurahan dengan kepadatan terrendah jika dilihat dari luas wilayah dibandingkan dengan jumlah penduduknya.

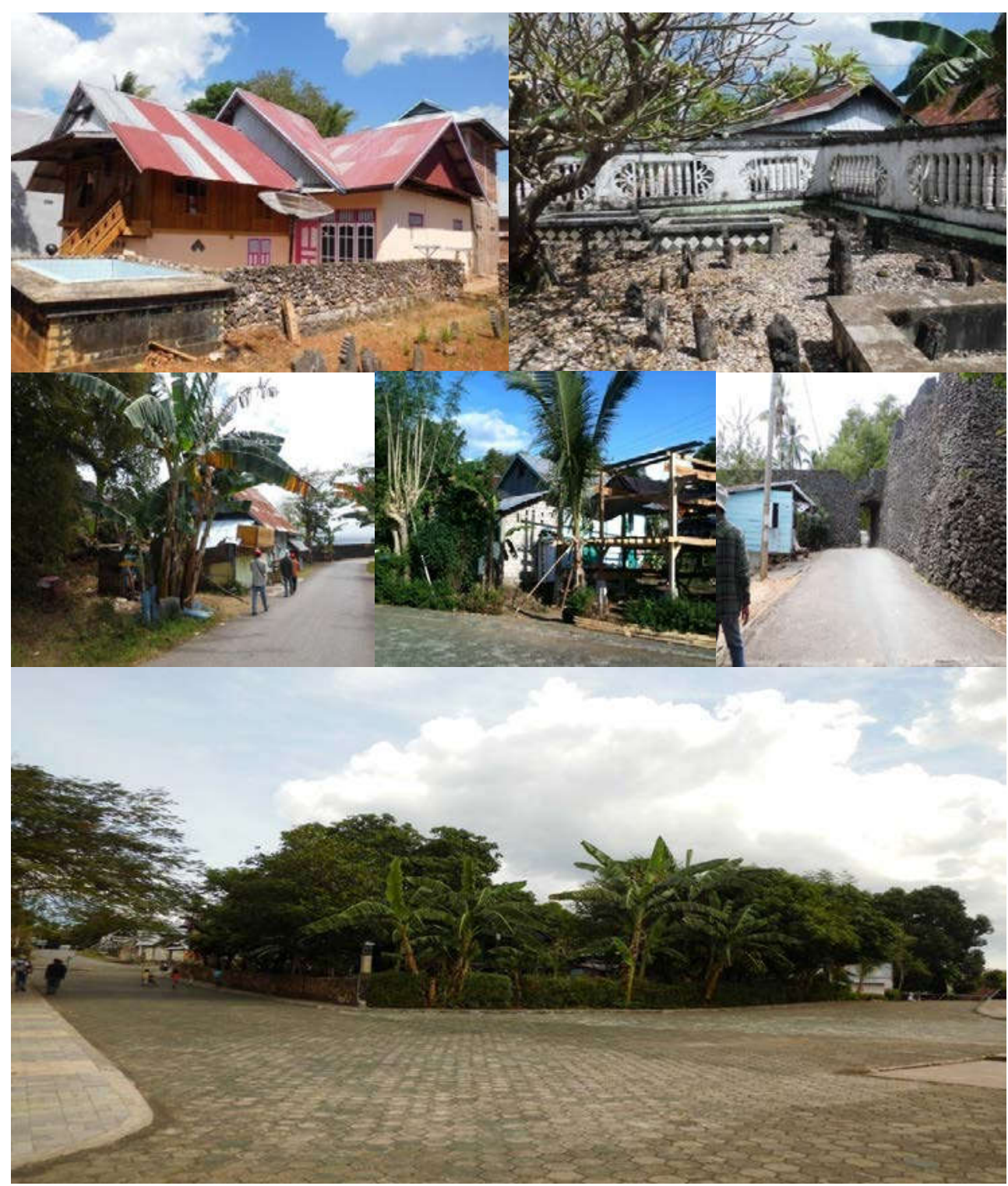

Gambar 5. Pemukiman penduduk disekitar Kompleks Makam dan dinding benteng (insert dalam kotak merah), beberapa bangunan yang mengancam kelestarian cagar budaya dari aspek kelayakan pandang (dok. BPCB Sul-Sel, 2012)

2. Sosial Ekonomi

Perkembangan pertumbuhan penduduk akan sangat berpengaruh terhadap perubahan lingkungan dan pemanfaatan sumberdaya alam dan diikuti dengan perubahan kehidupan sosial ekonomi masyarakat. Berdasarkan hasil pengamatan yang telah dilakukan, diketahui bahwa terjadi kepadatan pembangunan toko dan kios dalam kawasan Benteng Kraton Buton.
Kepadatan pembangunan ini terjadi karena semakin padatnya penduduk yang bermukim pada areal benteng dan di luar benteng. Hal ini merupakan salah satu cara masyarakat untuk memenuhi kehidupan ekonomi mereka tetapi tanpa mereka sadari hal yang dilakukan tersebut justu memberi dampak buruk terhadap tinggalan Cagar Budaya. 
3. Sosial Budaya

Berakhirnya kesultanan pada masa Muhamad Falihi yang merupakan sultan Buton terakhir (memerintah tahun 1938-1960), maka berakhir pula sistem kesultanan di Buton. Hal ini juga turut mempengaruhi pemukiman di kompleks Benteng Keraton Buton. Kompleks yang sebelumnya hanya boleh dihuni oleh dua golongan bangsawan (kaomu dan walaka), secara perlahan-lahan mengalami pergeseran, terutama menyangkut orang-orang yang bermukim di dalam wilayah Keraton Buton. Pada masa kesultanan, kompleks keraton dihuni oleh penguasa Kesultanan Buton, sebagaimana yang diungkapkan oleh Schoorl (2003) bahwa Kesultanan Buton terdiri atas dua lapisan masyarakat yaitu kaomu dan walaka. Mereka dikonsentrasikan di pusat kesultanan, semula di dalam benteng keraton (permukiman) Buton, dan kemudian meluas ke daerah di dekatnya yaitu Sorawolio dan Baadia (Schoorl, 2003:81).

Di Kesultanan Buton terdapat empat lapisan masyarakat (Schoorl, 2003:138). Lapisan pertama atau yang tertinggi dibentuk oleh kaomu, kaum bangsawan. Jabatan sultan dan beberapa jabatan lain dalam pemerintahan ini dipilih dan dipegang oleh anggota dari golongan ini. Lapisan kedua disebut walaka yang membagi kekuasaan pemerintahan dengan kaomu. Sebuah dewan yang terdiri dari sembilan walaka (siolimbona) memilih sultan dari golongan pertama. Golongan walaka adalah ahli dan penjaga adat. Antara dua lapisan masyarakat itu terdapat perimbangan kekuasaan tertentu. Kedua golongan ini berdomisili di Kompleks Benteng Keraton Buton.

Lapisan ketiga adalah papara, terdiri atas penduduk desa yang merdeka, mendiami daerah kadie (desa). Mereka tidak boleh tinggal di pusat (Keraton Buton) dan tidak ikut dalam pemerintahan kesultanan. Namun, mereka wajib menyerahkan upeti atau membayar pajak tahunan kepada kesultanan dan mengerjakan jasa-jasa tertentu, antara lain membela negeri. Lapisan keempat adalah batua (budak) yang bekerja untuk dua lapisan masyarakat yang pertama (Schoorl, 2003:138).

Pada masa kini, masyarakat yang berasal dari luar baik luar keraton maupun luar daerah Buton dapat tinggal di kompleks Keraton Buton. Mereka umumnya adalah perempuanperempuan yang diperisteri oleh lelaki yang berdomisili di keraton dan menetap atau tinggal di dalam Keraton Buton. Perbedaan antara satu lapisan dengan lapisan lainnya dipertahankan oleh sistem perkawinan dan kekeluargaan. Kedua sistem ini antara lain mengatur tempat seseorang dalam masyarakat yang bergantung pada garis keturunan melalui ayah.

Meskipun dari waktu ke waktu nilai sakral dari Keraton Buton secara perlahanlahan mulai memudar seiring perkembangan zaman, akan tetapi kegiatan-kegiatan seperti adat dan aktivitas keagamaan serta aktivitas bermukim masih ketat dengan aturan-aturan yang masih tetap dipertahankan sampai sekarang di kompleks Keraton Buton.

Tanah pendirian bangunan di kompleks Keraton Buton, bukanlah hak milik masyarakat setempat, namun tanah hak pakai sehingga masyarakat tidak dapat mengklaim bahwa tanah yang ditempati menjadi hak miliki mereka. Sejak berakhirnya kesultanan, tanah di kompleks tersebut tidak lagi menjadi kewenangan adat. Oleh karena itu, masyarakat (tokoh adat, tokoh agama, dan keluarga sultan) memberi kepercayaan kepada pemerintah Kota Bau-Bau untuk menjaga dan mengelola, serta mengawasi pendirian bangunan baru, terutama bangunan permanen, di kompleks tersebut. Dengan demikian, bagi siapapun tidak diperbolehkan untuk mendirikan rumah tinggal yang baru pada lahan kosong di kompleks Keraton Buton.

Namun berdasarkan dengan hasil pengamatan yang dilakukan diketahui bahwa perubahan kehidupan sosial ekonomi masyarakat yang bermukim di dalam Benteng Keraton Buton dan lingkungan di luar benteng sangat besar pengaruhnya terhadap kehidupan 
sosial budaya masyarakat. Salah satu bentuk perubahan yang terjadi dalam benteng yaitu pada bangunan perumahan. Pada awalnya ada aturan bagi masyarakat yang bermukim di dalam benteng tidak diizinkan membuat bangunan permanen, masyarakat yang bermukim harus membuat bangunan perumahan yang bersifat semi permanen yaitu bangunan rumah panggung. Namun bangunan perumahan masyarakat tidak lagi mempertahankan konsep bangunan tradisonal, tetapi kondisi sekarang menunjukkan bahwa bangunan perumahan masyarakat dibuat sebagai bangunan permanen yaitu dimana kolong rumah mereka manfaatkan juga sebagai tempat tinggal dan dibangun dengan menggunakan susunan batu gunung dan semen.

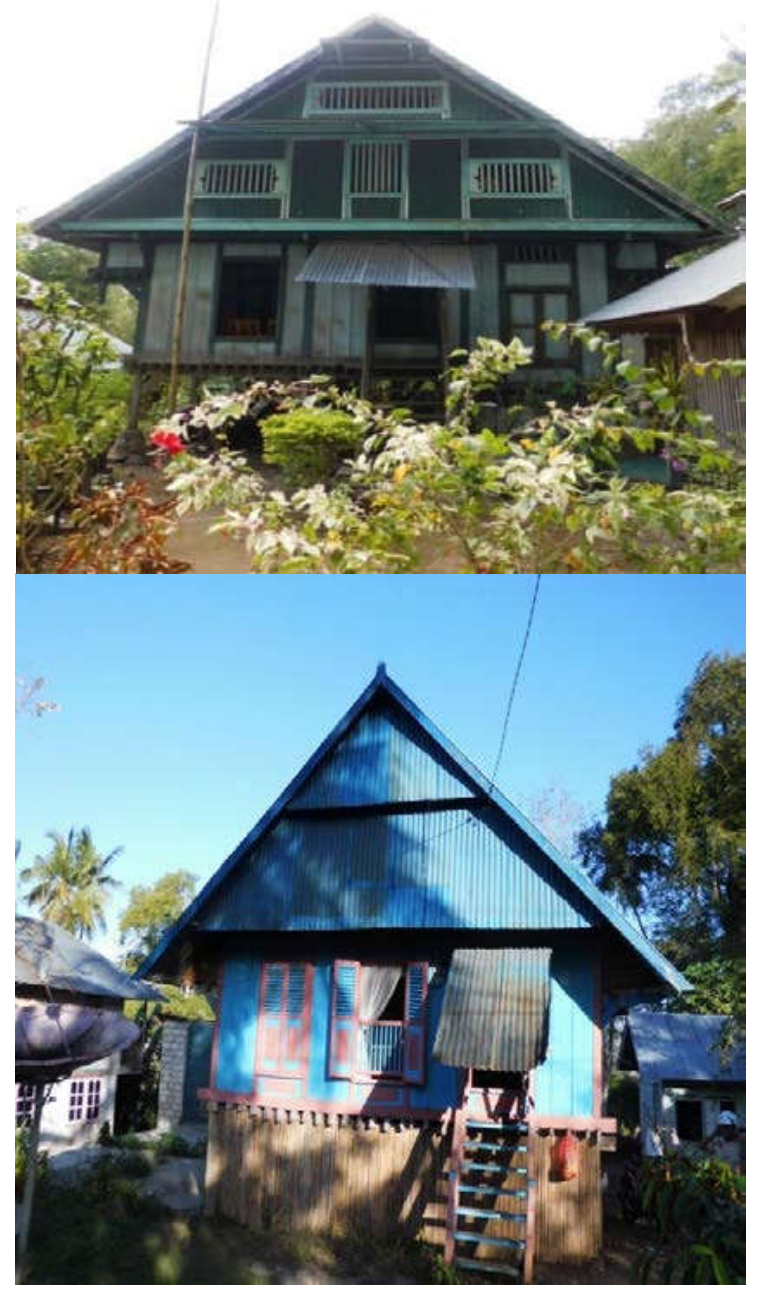

Gambar 6. Bentuk perumahan penduduk (dok. Dewi Susanti, 2012)

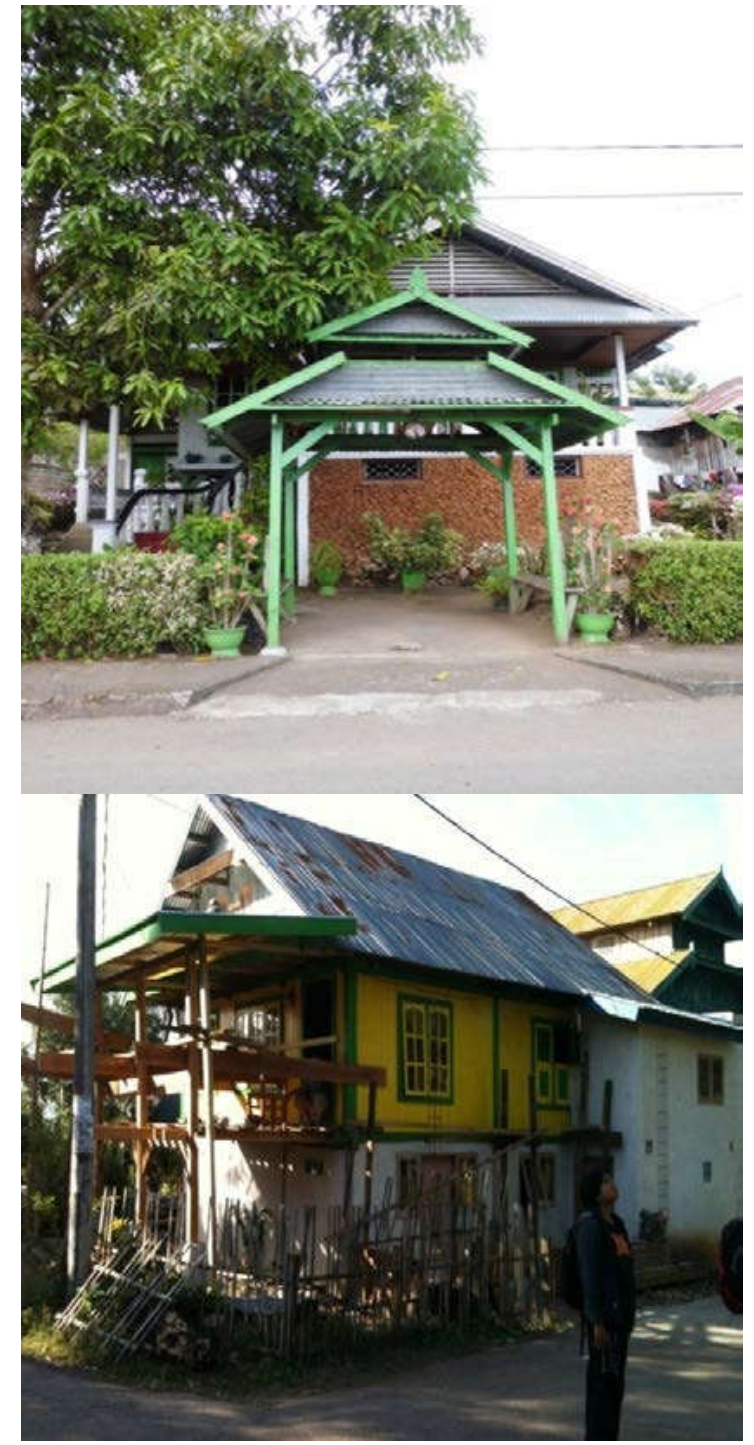

Gambar 7. Bentuk bangunan perumahan penduduk di dalam benteng (dalam kotak area: bagian yang telah dipermanenkan)

(dok BPCB Sul-Sel dan Dewi Susanti, 2012)

Perkembangan yang terjadi pada kawasan Benteng Keraton Buton lama kelamaan semakin pesat sehingga menyebabkan beberapa bangunan cagar budaya mengalami perubahan fungsi dan penambahan bangunan pada cagar budaya tersebut. Selain itu, karena perkembangan masyarakat yang semakin pesat, dengan populasi penduduk yang cukup tinggi mengakibatkan persediaan lahan semakin sempit. Melihat kondisi tersebut, menimbulkan dampak yang negatif terhadap tinggalan Cagar Budaya yang ada karena dimanfaatkan oleh masyarakat tidak sesuai dengan peruntukannya. Kondisi tersebut akan diuraikan sebagai berikut. 
1. Perubahan Fungsi Bangunan/ Ruang

Perubahan fungsi dan bentuk cagar budaya /ruang diakibatkan oleh kebutuhan pemerintah dan masyarakat yang semakin berkembang hal ini dapat kita lihat sebagai berikut.

a. Benteng Keraton Buton

BentengKeraton Buton pada dasarnya masih menunjukkan identitas sebagai situs, namun seiring dengan meningkatnya kebutuhan masyarakat dan terbatasanya lahan maka masyarakat cenderung memanfaatkan kawasan disekitar bangunan Cagar Budaya. Hal tersebut dapat kita lihat pada areal disekitar dinding Benteng Keraton Buton yang dimanfaatkan oleh masyarakat sebagai tempat untuk memelihara ternaknya.

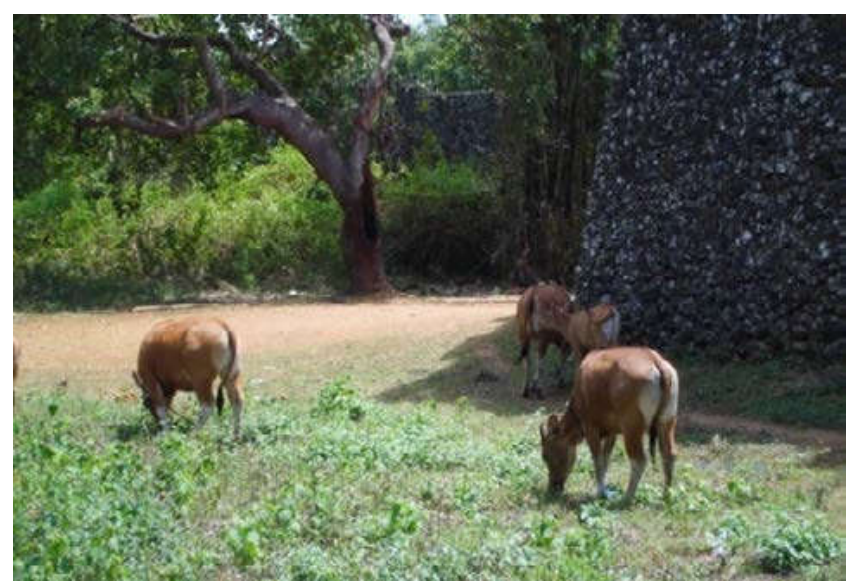

Gambar 8. Kawasan benteng yang dimanfaatkan sebagai tempat mengembala dan penyimpanan ternak (dok, BPCB Sul-Sel, 2012)

\section{b. Kamali Kara}

Bangunan kamali kara ini masih tetap difungsikan sebagai rumah tinggal tetapi bukan sebagai rumah tinggal Sultan. Bangunan telah beberapa kali mengalami perubahan, hal ini dapat kita lihat pada gambar (no.9). Pada bagian tangga terdapat atap yang difungsikan untuk mencegah terjadinya rembesan air ketika musim hujan. Namun kondisi bangunan pada saat ini, telah mengalami perubahan di beberapa bagian seperti pada bagian tangga. Kondisi tangga sekarang tidak lagi menggunakan atap sebagaimana bentuk awalnya. Selain itu, ukuran dan bentuk tangga juga mengalami perubahan. Kondisi bangunan sekarang lebih terbuka tetapi hal tersebut memberikan dampak yang negatif karena telah merubah bentuk asli dari bangunan tersebut. Dampak lain yang ditimbulkan adalah akan mempercepat terjadinya kerusakan dan pelapukan, hal ini disebabkan karena apabila terjadi musim hujan maka akan terjadi rembesan yang mengakibatkan tingkat kelembaban akan semakin tinggi.

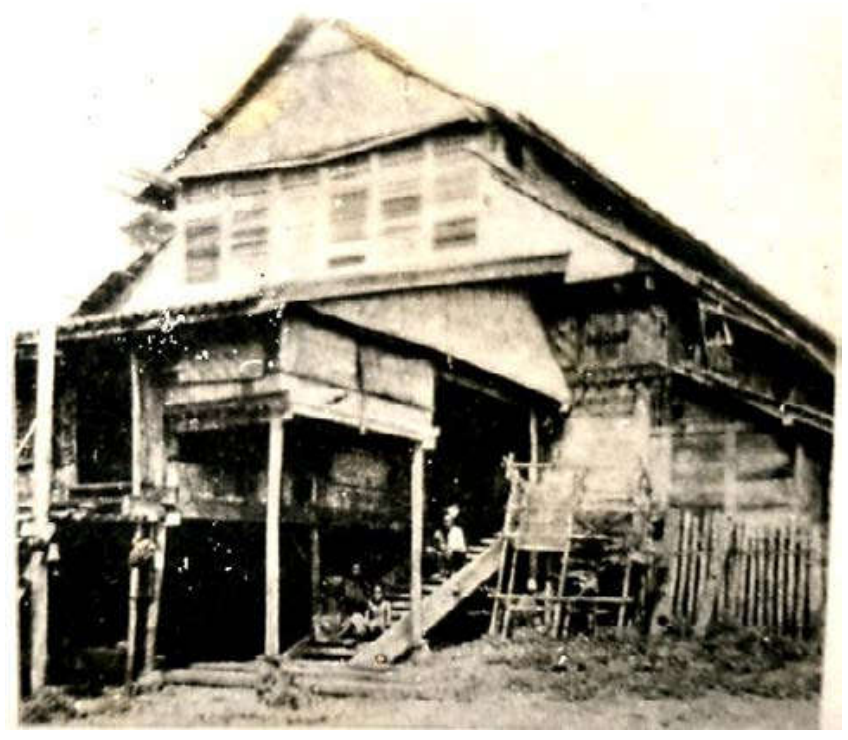

Gambar 9. Bangunan Kamali Kara (bangunan asli)

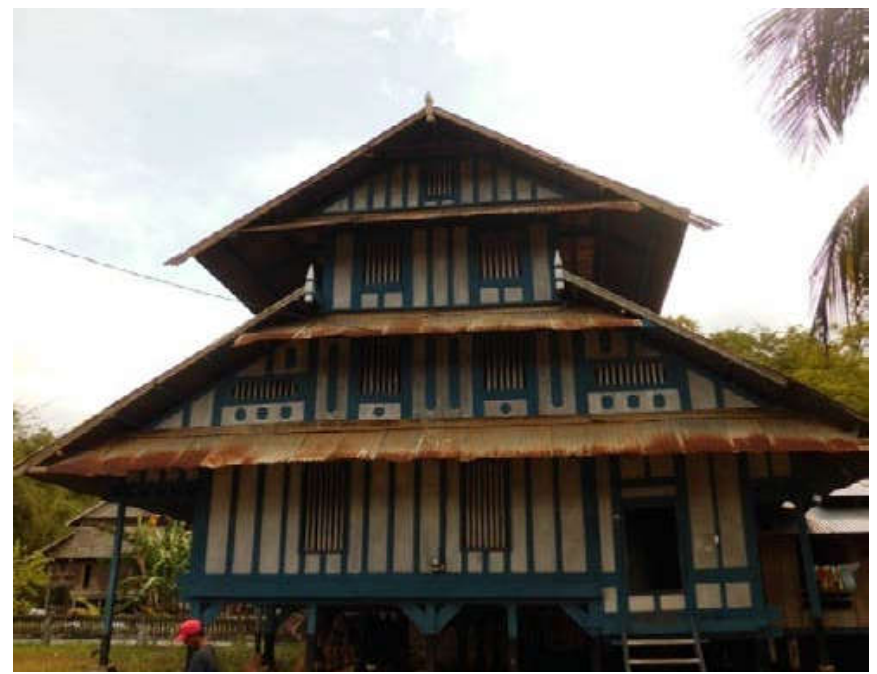

Gambar 10. Bangunan kamali kara (dokumentasi tim BPCB Sul-Sel, 2012) 
c. Penambahan Bangunan Baru

Akibat dari perkembangan masyarakat yang semakin pesat menyebabkan lahan yang tersedia semakin berkurang. Pemukiman penduduk semakin mengancam keberadaan tinggalan Cagar Budaya yang ada di dalam kawasan benteng dan yang diluar benteng, sehingga mempengaruhi kelayakan padang (visibilitas) yang sangat terbatas.

Keterbatasan disebabkan oleh bangunan
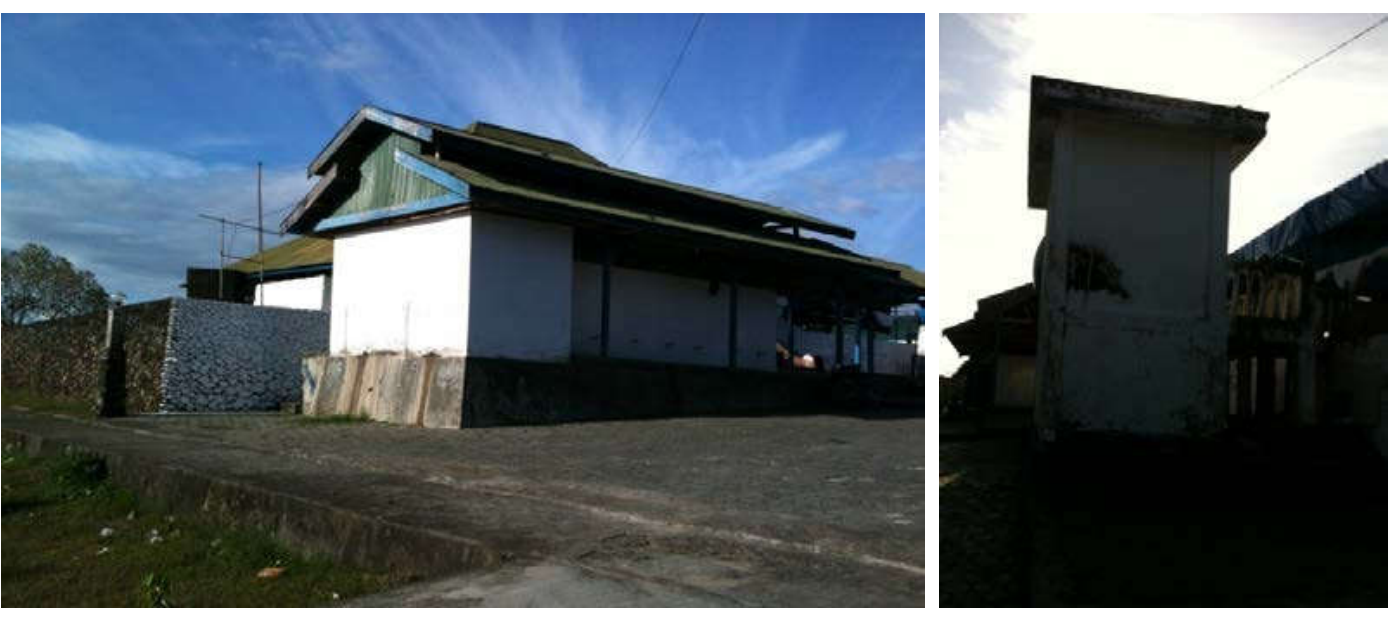

Gambar 11. Bangunan tambahan pada bangunan Masjid Keraton Buton (dok BPCB Sul-Sel, 2012)
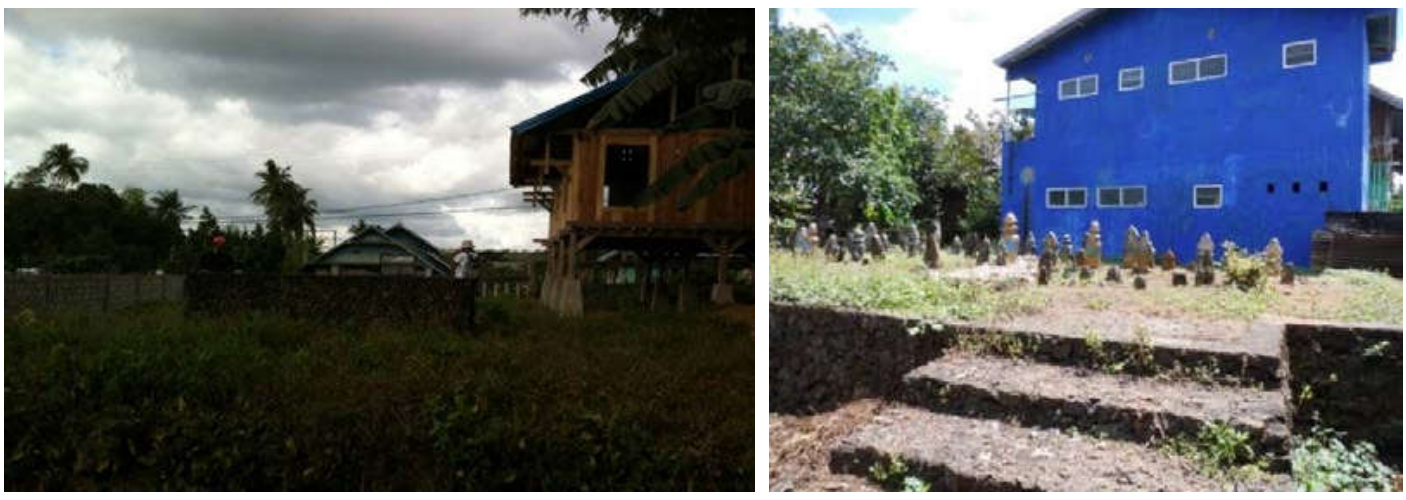

Gambar 12. Bangunan Baru disekitar Kompleks Makam (dok. Dewi Susanti,2012)

d. Jaringan Jalan

Jaringan jalan yang ada di dalam Kompleks Benteng Keraton Buton dan di luar Benteng Keroton Buton sangat mengkhawatirkan dan sangat mengancam keberadaan tinggalan Cagar Budaya yang ada di dalam kompleks Benteng dan di luar benteng. pemukiman penduduk yang semakin padat pada tinggalan Cagar Budaya yang ada di dalam Kompleks Benteng Keraton Buton. Penambahan bangunan baru dapat kita lihat pada gambar, dimana pada bagian dinding benteng terdapat bangunan baru, selain itu dapat juga di temukan pada Masigi Ogena dan Masjid Quba (lihat gambar) . 


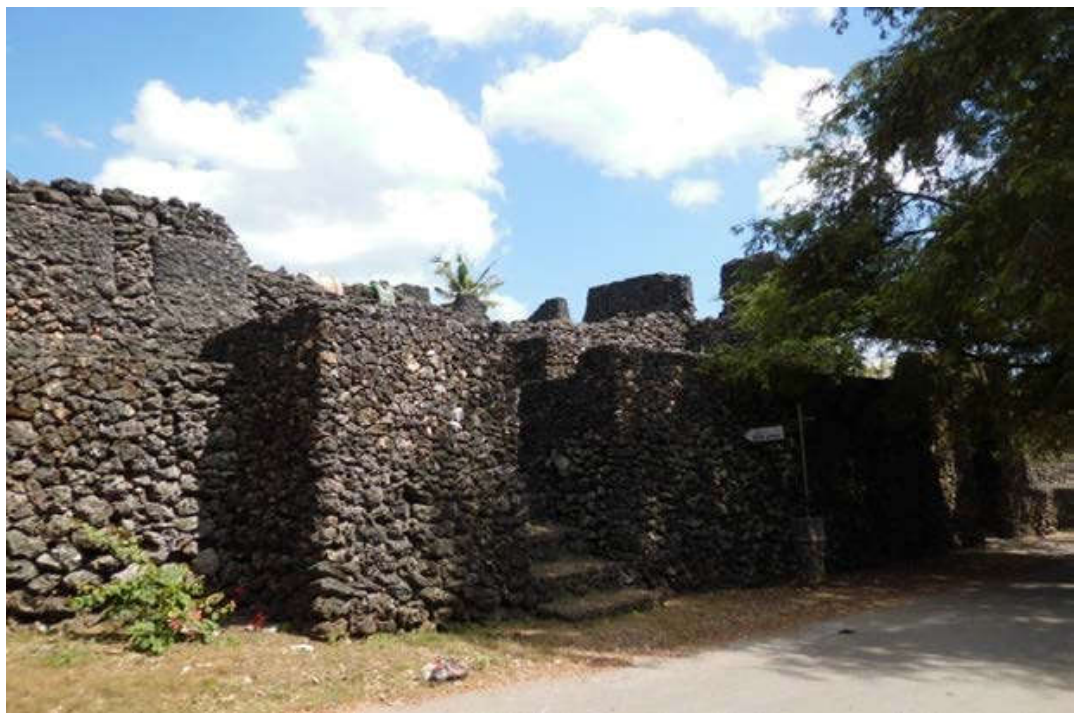

Gambar 13. Baluarana Lantogau, salah satu Baluarana yang jaraknya sangat dekat dengan badan jalan (dok. Dewi Susanti, 2012)
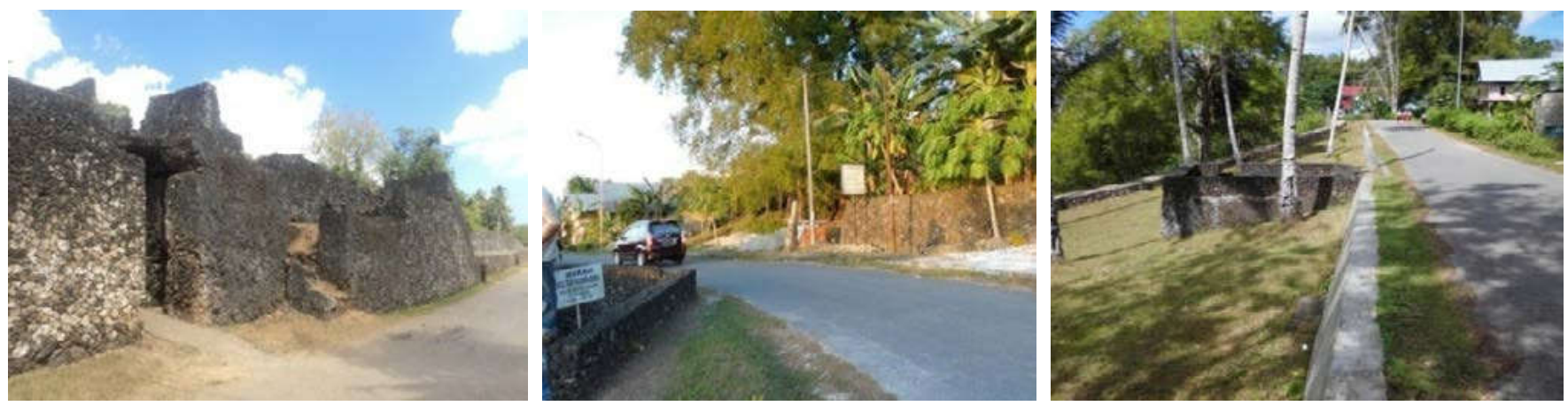

Gambar 14. Lawana Bariya, salah satu Lawana yang jaraknya sangat dekat dengan badan jalan (kiri) Makam sultan Nasiruddin (tengah), salah satu Makam yang jaraknya sangat dekat dengan badan jalan (kanan) insert;dalam kotak area (dok. BPCB Sul-Sel, 2012)

\section{Upaya Penyelesaian}

Upaya penyelesaian yang harus dilakukan terhadap tinggalan Cagar Budaya Benteng Keraton Buton yaitu pelindungan. Salah satu bentuk pelindungan yang dilakukan yaitu dengan melakukan zonasi. Tujuan yang ingin dicapai yaitu agar dapat mengatur peruntukan dan fungsi lahan yang ditujukan untuk pelestarian Kompleks Benteng Keraton Buton, beserta tinggalan budayanya baik yang intangible maupun tangible. Zonasi merupakan sistem penataan ruang dalam situs atau kawasan cagar budaya yang meliputi penentuan batas-batas keruangan dan fungsi masing-masing ruang. Hal ini tercantum dalam Bab 1 Ketentuan Umum, Pasal 1 butir 26 Undang-Undang Nomor 11 Tahun 2010, tentang Cagar Budaya yang mencantumkan bahwa zonasi adalah penentuan batas-batas keruangan Situs Cagar Budaya dan Kawasan Cagar Budaya sesuai dengan kebutuhan.

Lebih lanjut Pasal 72 mengatur mengenai penetapan batas-batas keluasan dan pemanfaatan ruang dalam situs dan kawasan berdasarkan kajian Pasal 73 Ayat (3), zonasi dapat terdiri dari: a. zona inti, b. zona penyangga, c. zona pengembangan, dan/atau d. zona penunjang. Selain itu dalam pasal yang sama pada ayat (4) dijelaskan bahwa penetapan luas, tata letak, dan fungsi zona ditentukan berdasarkan hasil kajian dengan mengutamakan peluang peningkatan kesejahteraan rakyat.

Selanjutnya, dalam penjelasan UU No. 11 Tahun 2010 diuraikan zona inti adalah area pelindungan utama untuk menjaga bagian 
terpenting cagar budaya, zona penyangga merupakan area yang melindungi zona inti, zona pengembangan merupakan area yang diperuntukan bagi pengembangan potensi Cagar Budaya bagi kepentingan rekreasi, daerah konservasi lingkungan alam, lanskap budaya, kehidupan budaya tradisional, keagamaan, dan kepariwisataan. Selanjutnya, dijelaskan pula bahwa zona penunjang adalah area yang diperuntukkan bagi sarana dan prasarana penunjang serta untuk kegiatan komersial dan rekreasi umum. Sesuai uraian diatas, berikut akan diuraikan mengenai regulasi yang ada di Kawasan Benteng Keraton Buton.

\section{a. Peruntukan lahan}

Sesuai dengan Undang-undang No. 11 Tahun 2010 tentang Cagar Budaya pasal 73 ayat (3) dan penjelasannya, huruf a yang dimaksud dengan "zona inti" adalah area pelindungan utama untuk menjaga bagian terpenting Cagar Budaya. Huruf b yang dimaksud dengan "zona penyangga" adalah area yang melindungi zona inti baik secara horizontal maupun vertikal. Huruf c yang dimaksud dengan "zona pengembangan” adalah area yang diperuntukan bagi pengembangan potensi Cagar Budaya bagi kepentingan rekreasi, daerah konservasi lingkungan alam, lanskap budaya, kehidupan budaya, tradisional, keagamaan dan kepariwisataan. Huruf d yang dimaksud dengan "zona penunjang” adalah area yang diperuntukan bagi sarana dan prasarana penunjang serta untuk kegiatan komersial dan rekreasi umum.

Berdasarkan data yang diperoleh maka dalam pelindungan berupa zonasi terhadap tinggalan Benteng Keraton Buton dibagi ke dalam empat zona, masing-masing memiliki peruntukan. Hal ini disesuaikan dengan kebutuhan lahan dan pemanfaatannya, berikut ini akan diuraikan peruntukan lahan masing-masing zona:

- Zona inti, Sesuai dengan peruntukannya zona inti diperuntukkan sebagai area utama sebuah situs guna kepentingan pelindungan dalam rangka pelestarian Situs Benteng
Keraton Buton. Selanjutnya zona inti tersebut dibagi lagi kedalam dua zona yaitu zona inti I, yang diperuntukkan sebagai area pelindungan utama untuk menjaga bagian terpenting Cagar Budaya. Zona Inti II, merupakan bagian dari area pelindungan yang diperuntukkan untuk menjaga bagian terpenting cagar budaya.

- Zona penyangga adalah area yang diperuntukkan melindungi zona inti baik secara horizontal maupun vertikal.

- Zona pengembangan adalah area yang diperuntukan bagi pengembangan potensi Cagar Budaya bagi kepentingan rekreasi, daerah konservasi lingkungan alam, lanskap budaya, kehidupan budaya, tradisional, keagamaan, dan kepariwisataan.

- Zona penunjang adalah area yang diperuntukan bagi sarana dan prasarana penunjang serta untuk kegiatan komersial dan rekreasi umum.

\subsection{Regulasi}

\section{Regulasi Zonasi Benteng Keraton Buton}

Regulasi zonasi dapat didefinisikan sebagai ketentuan yang mengatur tentang klasifikasi, notasi dan kodifikasi zona-zona dasar, peraturan penggunaan, peraturan pembangunan dan berbagai prosedur pelaksanaan pembangunan. Fungsi peraturan zonasi adalah:

a. Sebagai pedoman penyusunan rencana operasional. Peraturan zonasi dapat menjadi jembatan dalam penyusunan rencana tata ruang yang bersifat operasional, karena memuat ketentuan-ketentuan tentang penjabaran rencana dari yang bersifat makro ke dalam rencana yang bersifat meso sampai kepada rencana yang bersifat mikro (rinci).

b. Sebagai panduan teknis pemanfaatan lahan. Ketentuan-ketentuan teknis yang menjadi kandungan peraturan zonasi, seperti ketentuan tentang penggunaan rinci, batasanbatasan pengembangan persil dan ketentuanketentuan lainnya menjadi dasar dalam pengembangan dan pemanfaatan lahan.

c. Sebagai instrumen pengendalian pembangunan. Peraturan zonasi yang 
lengkap akan memuat ketentuan tentang prosedur pelaksanaan pembangunan sampai ke tata cara pengawasannya. Ketentuanketentuan yang ada karena dikemas dalam aturan penyusunan perundang-undangan yang baku dapat dijadikan landasan dalam penegakan hukum.

Beberapa aturan yang harus diterapkan pada zona inti I sebagaimana disebutkan di atas dapat diuraikan sebagai berikut:

Tabel 3. Aturan pada Zona Inti I

\begin{tabular}{|c|c|c|c|}
\hline No & Dapat dilakukan & Persyaratan & Tidak Dapat Dilakukan \\
\hline 1 & $\begin{array}{l}\text { Aktivitas Konservasi dan } \\
\text { pemugaran }\end{array}$ & $\begin{array}{l}\text { Ada izin dari instansi yang } \\
\text { berkompeten }\end{array}$ & $\begin{array}{l}\text { Aktivitas non konservasi, dan } \\
\text { pemugaran }\end{array}$ \\
\hline 2 & $\begin{array}{l}\text { Penelitian, pendidikan, } \\
\text { ilmu pengetahuan, dan } \\
\text { kebudayaan }\end{array}$ & $\begin{array}{l}\text { * Ada izin dari instansi yang } \\
\text { berkompeten; } \\
\text { * Tidak melakukan aktivitas yang } \\
\text { bersifat membongkar struktur } \\
\text { yang tidak mengikuti kaidah } \\
\text { arkeologi }\end{array}$ & $\begin{array}{l}\text { Aktivitas fisik, khususnya terkait } \\
\text { dengan penggalian tanah dan } \\
\text { pengrusakan struktur. }\end{array}$ \\
\hline 3 & Penataan & $\begin{array}{l}\text { Ada Izin dari Instansi yang } \\
\text { berkompeten } \\
\text { Didahului dengan studi } \\
\text { kelayakan atau kajian/penelitian }\end{array}$ & $\begin{array}{l}\text { Mengubah tata lingkungan asli } \\
\text { (yang ditemui sekarang), termasuk } \\
\text { menebang atau menanam pohon } \\
\text { yang dapat membahayakan struktur. }\end{array}$ \\
\hline 4 & Perkunjungan/rekreasi & $\begin{array}{l}\text { Ada izin dari instansi } \\
\text { berkompeten } \\
\text { Tidak melakukan pengrusakan } \\
\text { dan pencemaran }\end{array}$ & Kunjungan yang tak terkendali. \\
\hline
\end{tabular}

Untuk zona inti II, regulasi atau atau aturan yang diterapkan adalah sebagian besar aturan yang diterapkan pada zona inti I, kecuali ditambahkan beberapa hal yang dapat dilakukan, antara lain.

Tabel 4. Aturan pada Zona Inti II

\begin{tabular}{|c|c|c|c|}
\hline No & Dapat dilakukan & Persyaratan & Tidak Dapat Dilakukan \\
\hline 1 & $\begin{array}{l}\text { Pendirian bangunan non- } \\
\text { permanen dan bersifat } \\
\text { reversible atau mudah } \\
\text { dibongkar dan dipindahkan }\end{array}$ & $\begin{array}{l}\text { Ada izin dari instansi yang } \\
\text { berkompeten }\end{array}$ & Pendirian bangunan permanen \\
\hline 2 & $\begin{array}{l}\text { Mempertahankan bangunan } \\
\text { permanen yang telah ada }\end{array}$ & $\begin{array}{l}\text { Ada izin dari instansi yang } \\
\text { berkompeten; } \\
\text { Telah ada sebelum adanya } \\
\text { zonasi }\end{array}$ & $\begin{array}{l}\text { Menambah luas dan ketinggian } \\
\text { bangunan }\end{array}$ \\
\hline 3 & $\begin{array}{l}\text { Kegiatan pengolahan lahan/ } \\
\text { halaman rumah secara } \\
\text { terbatas }\end{array}$ & $\begin{array}{l}\text { Membongkar tanah sesuai } \\
\text { dengan kebutuhan untuk } \\
\text { tanaman tidak melebihi } 50 \mathrm{~cm} \text {. } \\
\end{array}$ & $\begin{array}{l}\text { Penanaman pohon jangka panjang } \\
\text { bertajuk tinggi, tanaman dengan } \\
\text { akar yang dapat merusak struktur } \\
\text { atau bangunan cagar budaya yang } \\
\text { terpendam di dalam tanah. }\end{array}$ \\
\hline
\end{tabular}




\begin{tabular}{|c|l|l|l|}
\hline 4 & $* \begin{array}{l}\text { Ada izin dari instansi } \\
\text { berkompeten } \\
\text { kenggalian tanah untuk } \\
\text { sanitasi }\end{array}$ & $\begin{array}{l}\text { Ada pengawasan dari instansi } \\
\text { yang berkompeten pada saat } \\
\text { penggalian }\end{array}$ & $\begin{array}{l}\text { Penggalian tanah untuk bangunan } \\
\text { permanen atau untuk kepentingan lain } \\
\text { yang tidak sesuai }\end{array}$ \\
\hline 5 & $\begin{array}{l}\text { Kegiatan pendidikan, sosial, } \\
\text { ekonomi, dan kebudayaan } \\
\text { yang tidak bertentangan } \\
\text { dengan prinsip-prinsip } \\
\text { pelestarian }\end{array}$ & $* \begin{array}{l}\text { Tidak mengganggu benda, } \\
\text { struktur, dan bangunan cagar } \\
\text { budaya yang ada }\end{array}$ & $\begin{array}{l}\text { Segala kegiatan yang bertentangan } \\
\text { dengan prinsip perlindungan cagar } \\
\text { budaya. }\end{array}$ \\
\hline
\end{tabular}

Sumber: Laporan zonasi Benteng Keraton Buton

Untuk aturan perlakuan lahan atau zona penyangga, sesuai dengan prinsipnya sebagai lahan pelindungan bagi zona inti ditambah dengan berbagai pertimbangan lain untuk menunjang pengembangan dan pemanfaatannya, maka beberapa hal sebagai berikut mutlak diberlakukan.

Tabel 5. Aturan pada Zona Penyangga

\begin{tabular}{|c|c|c|c|}
\hline No & Dapat dilakukan & Persyaratan & Tidak Dapat Dilakukan \\
\hline 1 & $\begin{array}{l}\text { Pendirian bangunan non- } \\
\text { permanen dan bersifat } \\
\text { reversible atau mudah } \\
\text { dibongkar dan dipindahkan }\end{array}$ & $\begin{array}{l}\text { * Ada izin dari instansi } \\
\text { yang berkompeten } \\
\text { Bangunan menggunakan } \\
\text { arsitektur yang } \\
\text { mencirikan arsitektur } \\
\text { tradisional/lokal } \\
\text { * Tidak menghalangi } \\
\text { pandangan terhadap } \\
\text { struktur atau bangunan } \\
\text { cagar budaya yang ada } \\
\text { dalam benteng } \\
\end{array}$ & $\begin{array}{l}\text { Pendirian bangunan } \\
\text { permanen, atau bangunan } \\
\text { yang dapat mengganggu } \\
\text { pandangan atau mengganggu } \\
\text { keserasian pandangan } \\
\text { terhadap benteng dan } \\
\text { lingkungan di sekitarnya }\end{array}$ \\
\hline 2 & Penataan lingkungan & $\begin{array}{l}\text { Ada Izin dari Instansi } \\
\text { yang berkompeten } \\
\text { * Didahului dengan studi } \\
\text { kelayakan atau kajian/ } \\
\text { penelitian } \\
\text { * Tidak mengubah setting } \\
\text { yang ada tanpa adanya } \\
\text { penelitian khusus } \\
\text { setting lingkungan yang } \\
\text { seharusnya } \\
\end{array}$ & $\begin{array}{l}\text { Mengubah tata lingkungan } \\
\text { asli (yang ditemui } \\
\text { sekarang), termasuk } \\
\text { menebang atau menambah } \\
\text { pepohonan yang tidak } \\
\text { sesuai dengan lingkungan } \\
\text { aslinya. } \\
\text { Mengubah fungsi lahan } \\
\text { yang ada sekarang }\end{array}$ \\
\hline 3 & $\begin{array}{l}\text { Pengolahan lahan sesuai } \\
\text { dengan fungsi sekarang, } \\
\text { misalnya sawah, tambak, } \\
\text { ataupun kebun. }\end{array}$ & $\begin{array}{l}\text { Mempertimbangkan } \\
\text { pengaruh aktivitas } \\
\text { terhadap kondisi zona inti }\end{array}$ & $\begin{array}{l}\text { Mengubah fungsi lahan } \\
\text { tanpa koordinasi dengan } \\
\text { instansi yang berkompeten. }\end{array}$ \\
\hline 4 & $\begin{array}{l}\text { Kegiatan sosial, ekonomi, } \\
\text { pendidikan, keagamaan, } \\
\text { budaya, penelitian dan } \\
\text { pengembangan ilmu } \\
\text { pengetahuan dan teknologi } \\
\text { yang tidak bertentangan } \\
\text { dengan prinsip pelestarian } \\
\text { cagar budaya }\end{array}$ & $\begin{array}{l}\text { Tidak menimbulkan } \\
\text { dampak negatif terhadap } \\
\text { upaya perlindungan } \\
\text { terhadap cagar budaya, } \\
\text { baik secara langsung } \\
\text { maupun tidak langsung. }\end{array}$ & $\begin{array}{l}\text { Kegiatan yang melanggar } \\
\text { etika, norma, maupun adat } \\
\text { istiadat atau kebiasaan } \\
\text { masyarakat setempat. } \\
\text { Menutup akses masyarakat } \\
\text { umum terhadap Benteng } \\
\text { Keraton Buton sebagai } \\
\text { struktur cagar budaya. }\end{array}$ \\
\hline
\end{tabular}


Tabel 6. Regulasi Zona Pengembangan

\begin{tabular}{|c|c|c|}
\hline No & Dapat dilakukan & Persyaratan/Anjuran \\
\hline 1 & $\begin{array}{l}\text { Pendirian atau penambahan bangunan } \\
\text { baru, baik permanen maupun non } \\
\text { permanen yang mendukung upaya } \\
\text { pemanfaatan }\end{array}$ & $\begin{array}{l}\text { Bangunan menggunakan arsitektur yang } \\
\text { mencirikan arsitektur tradisional/lokal } \\
\text { Tidak mendominasi atau tidak lebih mencolok } \\
\text { dibandingkan dengan bangunan benteng dan } \\
\text { bangunan di dalamnya. }\end{array}$ \\
\hline 2 & Penataan landscape dan lingkungan & $\begin{array}{l}\text { Tidak menghilangkan ciri khas lingkungan alami } \\
\text { situs, atau setidaknya masih mencerminkan } \\
\text { lingkungan asli situs. }\end{array}$ \\
\hline 3 & Kegiatan ekonomi & $\begin{array}{l}\text { * Sebaiknya melibatkan masyarakat di sekitarnya } \\
\text { sebagai pelaku ekonomi. } \\
\text { * Memberikan kontribusi terhadap pelestarian situs. }\end{array}$ \\
\hline 4 & $\begin{array}{l}\text { Kegiatan sosial, ekonomi, pendidikan, } \\
\text { keagamaan, budaya, penelitian dan } \\
\text { pengembangan ilmu pengetahuan dan } \\
\text { teknologi lainnya }\end{array}$ & * Tetap mempertimbangkan kelestarian situs. \\
\hline
\end{tabular}

Sumber: Laporan zonasi Benteng Keraton Buton

Pemanfaatan area dalam zona penunjang Benteng Keraton Buton harus mengikuti ketentuan sebagai berikut:

Tabel 7. Regurasi Zona Penunjang

\begin{tabular}{|c|l|}
\hline 1 & Pembangunan dan pengembangan harus sesuai nilai, tema dan nuansa Benteng Keraton Buton \\
\hline 2 & Pendirian bangunan yang memiliki ketinggian tidak melebihi dari ketentuan tata ruang yang berlaku \\
\hline 3 & Kegiatan menyesuaikan norma dan etika masyarakat, khususnya masyarakat setempat \\
\hline 4 & Tidak menutup akses publik terhadap Benteng Keraton Buton \\
\hline 5 & Memberi kontribusi terhadap pelestarian Benteng Keraton Buton \\
\hline 6 & Memberikan peluang untuk peningkatan kesejahteraan rakyat \\
\hline
\end{tabular}

Sumber: Laporan zonasi Benteng Keraton Buton

\section{PENUTUP}

Benteng Keraton Buton merupakan landmark Kota Bau-Bau, yang memiliki posisi sangat strategis. Mengingat bahwa wilayah ini memiliki tinggalan Cagar Budaya yang sangat bervariasi dan sangat berpotensi untuk dikembangkan sebagai objek wisata. Untuk menjadikan Benteng Keraton Buton sebagai salah satu tujuan destinasi wisata Kota Bau-Bau, hal utama yang perlu dilakukan adalah mengurangi tingkat terjadinya perubahan-perubahan fungsi lahan maupun bangunan yang ada di dalam kawasan Benteng Keraton Buton. Dengan demikian, maka secara tidak langsung tingkat kerusakan dan pelapukan yang terjadi pada kawasan benteng tersebut akan berkurang. Langkah awal yang perlu dilakukan adalah Deliniasi yang disertai dengan keterlibatan masyarakat setempat guna menjaga kelestarian Benteng Keraton Buton. Permasalahan lain yang dapat disimpulkan berdasarkan kondisi yang terjadi pada kawasan Benteng Keraton Buton adalah.

1. Ancaman terhadap situs terutama berasal dari aktivitas masyarakat misalnya perluasan pemukiman, perluasan lahan pertanian, pemakaman, modernisasi, dan kebijakan pemerintah.

2. Rendahnya pemahaman masyarakat setempat tentang pentingnya pelestarian terhadap Cagar Budaya yang ada di sekitar lingkungan mereka. 
3. Beberapa bangunan yang tergolong sumberdaya budaya, telah mengalami perubahan, renovasi tanpa disertai dengan studi kelayakan dan studi teknis terlebih dahulu. Hal ini jika terus dibiarkan akan mengakibatkan hilangnya nilai-nilai yang terkandung di dalamnya.

\section{DAFTAR PUSTAKA}

V. Anonim, 1983. Aspek Geografi Budaya dalam Wilayah Pembangunan Daerah Sulawesi Tenggara. Jakarta: Proyek Inventarisasi Kebudayan Daerah Depdikbud RI

., Peraturan Pemerintah Nomor 10 Tahun 1993

Tentang Pelaksanaan Undang-Undang No 5

Tahun 1992 Tentang Benda Cagar Budaya

, Keputusan Menteri Negara Lingkungan Hidup Nomor: Kep- 49/MENLH/11/1996 Tentang Baku Tingkat Getaran

, Pusat Kajian Indonesia Timur (PUSKIT) Universitas Hasanuddin. 2005. Buku Panduan (Trail Map) Benteng Wolio (Buton). Bekerjasama dengan Dinas Pariwisata, Seni dan Budaya Kota Bau-Bau.

2010. Laporan Pemintakatan (zoning) Benteng Ujungpandang, Kota Makassar. Makassar, Balai Pelestarian Peninggalan Purbakala Makassar.

2011. Laporan Pemintakatan (zoning) Rumah Jabatan Gubernur Sulawesi Selatan, Kota Makassar. Makassar, Balai Pelestarian Peninggalan Purbakala Makassar.

, Undang-Undang Nomor 11 Tahun 2010 Tentang Cagar Budaya

2011. Bau-bau Dalam Angka 2011. Kerjasama antara Badan PerencanaanPembangunan Daerah dan Penanaman Modal Kota Baubau dengan Badan Pusat Statistik Kota Baubau.

Astjario dan Siregar. 2004. 'Kecepatan Pengangkatan Pulau Buton dan Jejak Perubahan Muka Air Laut di Zaman Kuarter" dalam http://www.mgi.esdm. go.id/Artikel/tabid/92/currentpage/2/Default. aspx diakses tanggal 23 Maret 2009
4. Peran pemerintah daerah, pemerintah pusat, tokoh masyarakat, tokoh adat serta seluruh lapisan masyarakat sangat dibutuhkan perhatiannya dalam menjaga dan melestarikan Benteng Keraton Buton.

Awat, Rustam. 2007. "Alternatif Pengembangan Sumberdaya Budaya di Keraton Buton, Sulawesi Tenggara”. Tesis. Yogyakarta: Universitas Gadjah Mada.

Bowlder, Sandra. 1984. Archaeological Significance as a Mutable Quality. Dalam Sharon Sullivan \& Sandra Bowlder (ed.), Site Surveys and Significance Assessment in Australian Archaeology. Canberra: The Australian National University hlm. 1-9.

Cortesao, Armando. 1944. The Suma Oriental of Tomé Pires: an Account of the East, from the Red Sea to Japan, Written in Malacca and India in 1512-1515. Vol.1. Hakluyt Society. London: Kraus Reprint Limited.

Haliadi. 2000. "Buton Islam dan Islam Buton: Islamisasi, Kolonialisme, dan Sinkretisme Agama 18731938”. Tesis. Yogyakarta: Universitas Gadjah Mada.

Ikram, Achadiati. dkk. 2001. Katalog Naskah Buton, Koleksi Abdul Mulku Zahari. Jakarta: Masyarakat Pernaskahan Nusantara dan Yayasan Obor Indonesia

Keputusan Walikota Nomor 105 Tahun 2003. "Penetapan Benteng Keraton Buton sebagai Kawasan Khusus Kota Bau-Bau." Dalam Lembaran

Daerah Kota Bau-Bau Nomor 19 Tahun 2003.

Reid, Anthony. 1988. Southeast Asia in the Age of Commerce 1450-1680. Vol. 1. The Lands Below the Winds. New Haven and London: Yale University Press.

Said, Andi Muhammad., 2000. Pemintakatan Arkeologi: Suatu Upaya Pelestarian Gua Prasejarah MarosPangkep, Sulawesi Selatan. Tesis, Jakarta Program Pascasarjana Universitas Indonesia. Tidak Terbit. 
Schaafma, Curtis F. 1989. Significant Until Proven Otherwise: Problems Versus Representative Samples, dalam Henry Cleere (ed), Archaeological Heritage Management in The Modern World. London: Unwin-Hyman

Schoorl, Pim. 2003. Masyarakat, Sejarah dan Budaya Buton. Jakarta: Penerbit Jambatan Bekerjasam dengan Perwakilan KITLV Jakarta.

Tanudirjo, Daud Aris. 2004. "Penetapan Nilai Penting dalam Pengelolaan Benda Cagar Budaya", Makalah dalam Rapat Penyusunan Standardisasi Kriteria (Pembobotan) Bangunan Benda Cagar Budaya di Rumah Joglo Rempoa, Ciputat, Jakarta, 26 - 28 Mei 2004.
Wahidin, La Ode Muhamad Budi (dkk). 2003. Upacara Siklus Hidup (Life Cycle) Manusia dalam Kebudayaan Wolio Buton. Kerjasama Dinas Pendidikan Kota Bau-Bau, Dinas Pariwisata, Seni dan Budaya Kota Bau-Bau, dan Pusat Kajian dan Konservasi Kebudayaan Buton Yayasan Budi Mulia.

Zuhdi, Susanto. 1999. "Labu Rope Labu Wana: Sejarah Buton Abad XVII-XVIII”. Disertasi. Jakarta: Universitas Indonesia. 